\title{
PENGARUH PEMBERIAN MINUMAN BERENERGI SUBAKUT TERHADAP GAMBARAN HISTOLOGI GINJAL TIKUS PUTIH STRAIN WISTAR
}

\author{
Utari Prasetyaning 1 , Desy Andari², SM. Agustini ${ }^{3}$
}

Fakultas Kedokteran Universitas Muhammadiyah Malang, J1. Bendungan Sutami No. 188A, Kota Malang, 65145, Indonesia, (0341)551149

\begin{abstract}
ABSTRAK
Penelitian ini bertujuan untuk membuktikan adanya pengaruh pemberian minuman berenergi subakut terhadap gambaran histologi ginjal tikus putih strain wistar. Metode : Eksperimen laboratoris dengan rancangan the post test only control group design. Sampel dibagi dalam 4 kelompok. Kelompok I (K) tanpa pemberian minuman berenergi,kelompok II. III dan IV (P1, P2, P3) diberikan minuman berenergi $72 \mathrm{mg}, 216 \mathrm{mg}$ dan $360 \mathrm{mg}$. Analisis data menggunakan One Way Anova, uji Tukey, uji korelasi dan uji regresi. Hasil : Hasil uji One Way Anova dan uji Tukey didapatkan nilai sig=0,000 $(\mathrm{p}<0,05)$ artinya terdapat pengaruh yang signifikan antara perlakuan dengan jumlah sel nekrosis dan terdapat perbedaan yang bermakna antar kelompok. Hasil uji korelasi dan regresi didapatkan $\mathrm{r}=0,988$ dan $\mathrm{R} 2=0,976$ artinya semakin tinggi dosis akan diikuti oleh peningkatan jumlah sel nekrosis. Kesimpulan : Minuman berenergi dapat meningkatkan jumlah sel nekrosis pada sel epitel tubulus proksimal ginjal.
\end{abstract}

Kata kunci : Minuman berenergi, kafein, histologi ginjal, nekrosis sel epitel tubulus proksimal ginjal

ABSTRACT

The objectives of this research were to prove the effect of orally energy drinks subacute to the kidney histological appearance in white rat strain wistar. Method : Laboratory experiment by using the post test only control group design. The sample was divided into 4 groups. Group I (K) without energy drink, group II, III and IV (P1, P2, P3) with $72 \mathrm{mg}, 216 \mathrm{mg}$ and $360 \mathrm{mg}$ of energy drink. Data analysis used One Way Anova, Tukey test, correlation test and regression test. Result : One Way Anova test and tukey test result's obtained value sig=0,000 $(p<0,05)$ means there is a significant effect between treatments with a number of cell necrosis and there are significant differences between groups. The correlation test and regression test result of value $r=0,988$ and $\mathrm{R} 2=0,976$ which means the higher the dosage will be followed by an increase in number of cell necrosis. Conclusion : Energy drinks can increase number of cell necrosis in renal proximal tubular epithelial cells.

Keywords : Energy drinks, caffeine, renal histology, necrosis of renal proximal tubular epithelial cells

\section{PENDAHULUAN}

\section{Minuman Berenergi}

Konsumsi minuman berenergi semakin meningkat sejak pertama kalinya muncul minuman Red Bull pada tahun 1997. Pada tahun 2006, lebih dari 500 minuman berenergi baru diperkenalkan di seluruh dunia (Malinauskas, 2007). Pada dasarnya minuman berenergi adalah minuman yang mengandung kafein, taurin, vitamin B kompleks, ekstrak herbal dan gula atau pemanis yang dapat memberikan efek yang diinginkan oleh penggunanya seperti meningkatkan energi, konsentrasi, kewaspadaan, mempertahankan kekuatan fisik, mengurangi kantuk serta membuat daya pikir menjadi lebih jernih (Seifert, 2011).

Minuman berenergi adalah minuman ringan yang dapat meningkatakan energi, mengurangi atau mencegah kelelahan, meningkatkan ketahanan fisik, memperbaiki mood dan kemampuan kognitif melalui stimulasi sistem metabolik dan sistem saraf pusat. Secara umum minuman berenergi mengandung zat stimulan seperti kafein, ekstrak herbal (seperti guarana dan ginseng), vitamin B kompleks, asam amino (contohnya taurin) dan derivat gula (Malinauskas, 2007; Nienhueser, 2009). Efek minuman berenergi tersebut dapat dirasakan 30- 60 menit setelah pemakaian dan dipertahankan selama sekurangkurangnya 90 menit (Duchan, 2010)

Kafein merupakan kandungan utama dari minuman berenergi yang menimbulkan efek tersebut (Babu, 2008). Namun telah ditemukan bahwa kafein memiliki efek yang berbahaya yang dapat merusak tubuh (Malinauskas, 2007). Germany's poison center menemukan beberapa kasus terkait minuman energi sejak tahun 2002, salah satu hasil yang diperoleh adalah gagal ginjal (Seifert, 2011). Hal ini juga didukung oleh penelitian mengenai pemberian minuman berenergi merek X selama 30 hari (subakut) yang menunjukkan penurunan fungsi ginjal (Nova, 2009). Disamping itu juga telah dilakukan penelitian mengenai pemberian minuman berkafein yang memperlihatkan kerusakan tubulointersitial ginjal (Gerhastuti, 2009). 
Kafein adalah derivat xantin yang mengandung gugus metil yang merupakan perangsang susunan saraf pusat yang paling kuat (Gunawan, 2009). Kafein terdapat dalam teh, kopi, cokelat, minuman kola, obatobatan tertentu dan merupakan kandungan utama dari minuman berenergi (Babu, 2008). Kafein merupakan alkaloid putih dengan rumus senyawa kimia $\mathrm{C} 8 \mathrm{H} 10 \mathrm{~N} 4 \mathrm{O} 2$, dan rumus bangun 1,3,7-trimetilxantin (James, 2000).

Pada umumnya zat yang masuk ke dalam tubuh akan mengalami absorbsi, distribusi, metabolisme dan ekskresi. Ginjal merupakan organ ekskresi utama yang sangat penting untuk mengeluarkan sisa-sisa metabolisme, termasuk zatzat toksik yang tidak sengaja masuk ke dalam tubuh. Hal ini disebabkan banyak zat kimia yang diekskresi melalui urin. Selain itu, ginjal juga menerima aliran darah yang besar dan glomerulus ginjal mempunyai area permukaan luas yang memungkinkan terjadinya paparan dengan zat kimia. Kemampuan ginjal untuk mengkonsentrasikan larutan dan substansi juga menjadikan ginjal rentan terhadap perusakan oleh zat kimia (Katzung, 2002; Guyton, 2007).

\section{Ginjal}

Salah satu bagian ginjal yang paling sering terjadi kerusakan disebabkan zat kimia adalah tubulus proksimal. Tubulus proksimal peka terhadap anoksia dan mudah hancur karena keracunan akibat kontak dengan bahan-bahan yang diekskresikan melalui ginjal. Kerusakan yang sering terjadi adalah nekrosis tubulus dan hiperplasi atau hipoplasi tubulus. Bagian lain dari ginjal yang dapat terkena kerusakan adalah loop Henle dan glomerulus (Kram, 2001).

Perubahan morfologi sebagai akibat jejas nonletal sel dinamakan degenerasi atau jejas reversibel. Perubahan tersebut antara lain pembengkakan sel dan perubahan berlemak. Dalam hal ini, hubungannya dengan paparan zat kimia terhadap ginjal, menyebabkan pembengkakan sel epitel tubulus proksimal dan tubulus distal ginjal. Pada jejas tahap lanjut dapat menyebabkan nekrosis tubulus yang ditandai dengan kerusakan inti sel tubulus berupa kariolisis, piknosis, ataupun karioreksis (Robbins, 2005). Menurut Yayasan Ginjal Diatrans Indonesia (YGDI), jumlah penderita gagal ginjal terus meningkat. Data dari Perhimpunan Nefrologi Indonesia menyebutkan, saat ini sedikitnya terdapat 110.000 penderita gagal ginjal terminal (tahap akhir).

Gagal ginjal di Indonesia dan negara yang sedang berkembang umumnya disebabkan glomerulonephritis, yaitu penyakit autoimun yang dicetuskan infeksi. Penyebab lain yang meningkat ialah diabetes, hipertensi, batu ginjal, penggunaan obat-obatan dan pemakaian suplemen, jamujamuan, makanan dan minuman yang bersifat nefrotoksik (Yayasan Ginjal Diatrans Indonesia, 2010). Berdasarkan uraian diatas penelitian ini bertujuan untuk membuktikan apakah pemakaian minuman berenergi subakut dapat berpengaruh terhadap gambaran histologi ginjal.

Ginjal merupakan organ berbentuk seperti kacang yang terletak di kedua sisi kolomna vertebralis. Ginjal kanan terletak lebih rendah $1-2 \mathrm{~cm}$ daripada ginjal kiri oleh karena tertekan oleh hati. Kutub atas ginjal kanan terletak setinggi iga kedua belas sedangkan yang kiri setinggi iga kesebelas.
Ginjal terletak di bagian belakang abdomen atas, di belakang peritoneum, di depan dua iga terakhir, dan tiga otot besar - transversus abdominis, kuadratus lumborum, dan psoas mayor. Ginjal dipertahankan oleh bantalan lemak yang tebal agar posisinya tidak berubah. Di bagian atas kutub ginjal, masing - masing terdapat kelenjar adrenal (Price, 2005). Ginjal terlindung dengan baik dari trauma langsung - di sebelah posterior dilindungi oleh iga dan otot - otot yang meliputi iga dan dilindungi oleh bantalan usus yang tebal.

Bila ginjal mengalami cedera, maka hampir selalu terjadi akibat kekuatan yang mengenai iga kedua belas, yang berputar ke dalam dan menjepit ginjal di antara iga itu sendiri dengan korpus vertebra lumbalis. Perlindungan sempurna ini menyababkan ginjal dengan sendirinya sukar untuk diraba dan juga sukar dicapai sewaktu pembedahan (Price, 2005). Berat ginjal masing - masing adalah $130-150$ gr dengan ukuran panjang sekitar $11 \mathrm{~cm}$, lebar sekitar 4-5 cm dan tebal sekitar $3 \mathrm{~cm}$ (Gartner, 2007). Permukaan ginjal halus dan terdapat di dalam suatu kapsul yang dikelilingi oleh lemak perinefrik dan fasia Gerota (Chandrasoma, 2005).

Pada keadaan pembesaran massa ginjal dapat ditandai dengan pergeseran lemak perinefrik (Effendi, 2007). Ginjal juga memiliki sisi medial cekung dan permukaan lateral yang cembung. Sisi medial yang cekung, hilum, merupakan tempat masuknya saraf, keluar dan masuk pembuluh darah dan pembuluh limfe, serta keluarnya ureter (Junqueira, 2005).

Fungsi primer ginjal adalah regulasi volume, osmolalitas, elektrolit, konsentrasi asam basa cairan tubuh dengan mengeksresikan air dan elektrolit dalam jumlah yang cukup untuk mencapai keseimbangan elektrolit dan cairan tubuh total dan untuk mempertahankan konsentrasi normalnya dalam cairan ekstra selular.

Dalam melaksanakan berbagai fungsi di atas, di dalam ginjal terdapat peristiwa filtrasi, reabsorbsi, dan sekresi (Price, 2005). Ginjal melasanakan fungsinya dengan mekanisme filtrasi plasma yang terjadi di sepanjang kapiler glomeulus, mekanisme reabsorbsi dan sekresi berbagai zat yang berlangsung di sepanjang tubulus. Mekanisme tersebut mengubah komposisi akhir dan volume urin secara drastis apabila dibandingkan dengan cairan yang masuk ke nefron melalui kapiler glomerulus. Ginjal menerima sekitar 20\% hingga 25\% dari curah jantung atau sekitar 1000 hingga $1200 \mathrm{ml} /$ menit untuk difiltrasi. Semua elemen akan mengalami filtrasi, termasuk air, elektrolit dan nonelektrolit, kecuali untuk sel darah merah dan sebagian besar protein (Corwin, 2000).

Transport ion dan molekul melalui peristiwa reabsorbsi dan sekresi di sepanjang tubulus melalui mekanisme transport aktif atau pasif. Molekul-molekul air bergerak secara osmosis jika terdapat gradien konsentrasi ion-ion atau molekul yang melewati membran semipermeabel. Sejumlah dua pertiga dari hasil filtrasi glomerulus diabsorbsi kembali oleh tubulus proksimal, dan hanya sekitar 1\% yang diekskresikan ke dalam urin (Price, 2005). 


\section{KERANGKA KONSEP}
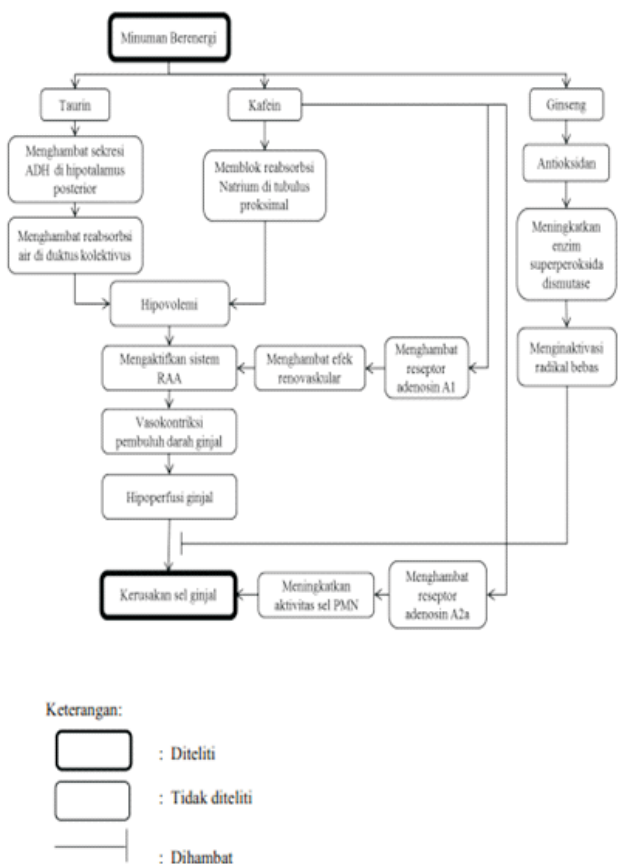

Minuman berenergi adalah minuman yang mengandung kafein, taurin, vitamin B kompleks dan ginseng (Seifert, 2011). Kafein dan taurin memiliki efek diuresis yang menyebabkan hilangnya air dan $\mathrm{Na}+$ dari dalam tubuh dimana taurin bekerja dengan cara menghambat sekresi Anti Diuretic Hormone (ADH) yang merupakan hormon yang dapat meningkatkan reabsorpsi air pada duktus kolektivus (Scientific Committee on Food, 2003; O'Callaghan, 2007). Sedangkan kafein bekerja dengan cara memblok reabsorpsi $\mathrm{Na}+$ di tubulus proksimal dan menyebabkan makula densa mendeteksi kadar $\mathrm{Na}+$ yang tinggi pada tubulus distal dan mengaktifkan sistem renin angiotensin aldosteron (Stewart, 2002).

Selain itu kafein merupakan antagonis reseptor adenosin A1 yang menyebabkan penghambatan efek renovaskular dan menyebabkan sekresi angiotensin meningkat (Tofovic, 2002). Angiotensin akan memicu vasokontriksi arteriol, hipoperfusi kapiler peritubuler postglomerulus dan hipoksia tubulointerstisial yang akan mengurangi pengiriman oksigen dan nutrisi ke tubulus sehingga dapat menyebabkan kerusakan tubulus (Nangaku, 2006). Kafein juga merupakan antagonis reseptor adenosin A2a yang menyebabkan aktivasi polymorphonuclear cell (PMN) meningkat sehingga dapat meningkatkan resiko inflamasi yang selanjutnya akan menyebabkan perubahan progresif yang lambat terhadap gambaran histologi ginjal (Moneim, 2009; Geoffrey, 2006).

\section{HIPOTESIS}

Terdapat pengaruh pemberian minuman berenergi subakut terhadap gambaran histologi ginjal tikus putih strain wistar.

\section{METODE PENELITIAN}

Penelitian ini merupakan penelitian eksperimental dengan menggunakan metode The Post Test Only Control Group Design. Penelitian ini akan dilaksanakan selama 1 bulan bertempat di Laboratorium Biokimia dan laboratorium Biomedik Fakultas Kedokteran Universitas Muhammadiyah Malang. Populasi penelitian adalah tikus putih (Rattus novergicus) strain wistar dewasa, jenis kelamin jantan, umur 2-3 bulan, berat badan 150-250 gram dengan kondisi sehat yang ditandai dengan gerakannya yang aktif.

\section{Alat dan Bahan}

Timbangan untuk menimbang berat badan tikus, Gelas ukur, Botol air dan botol minuman berenergi, Beker gelas, Spuit mikro, Sonde modifikasi, Alat untuk pengambilan organ: Alat bedah (minor, Hanscoon, Tabung film untuk tempat pengawetan organ sementara), Mikroskop, Mikrotom, Cover glass dan obyek glass.

Bahannya adalah hewan percobaan, makanan tikus, Pengukuran variable, minuman berenergi, Formalin 100\%.

Bahan untuk membuat sediaan histologi ginjal tikus dengan cara cervical dislocation (Pritchard et al, 1982); - Paraffin - Alcohol 30\%, 50\%, 70\%, 85\%, 95\%, 100\% - Xilol Hematoxilin dan eosin - Formalin 100\% dan Aquades

\section{Alur Penelitian}

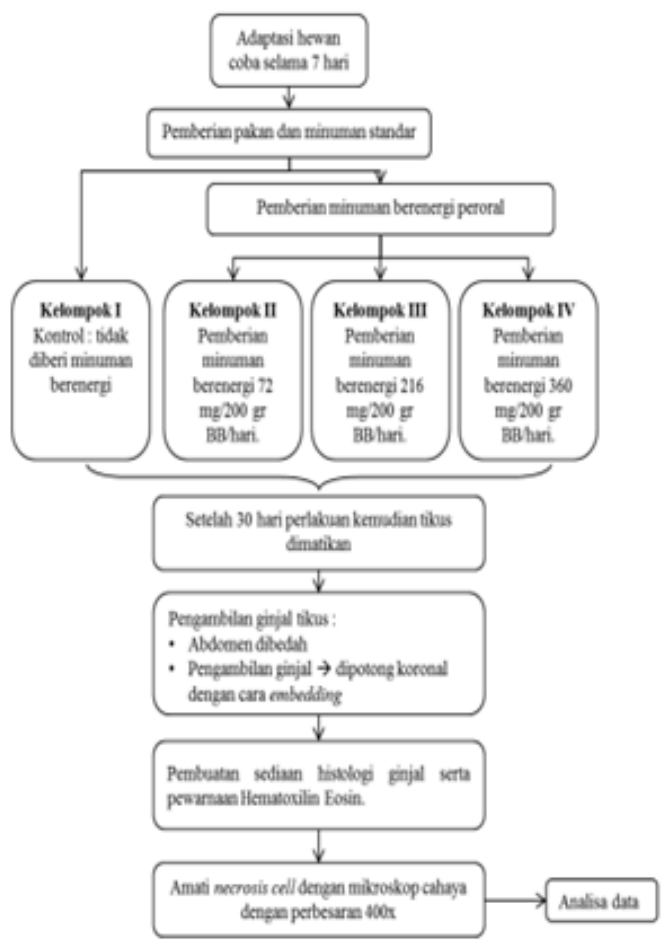

\section{Percobaan}

\section{Pemberian minuman berenergi}

Kelompok I sebagai kelompok kontrol. Kelompok I ini tidak diberi minuman berenergi. Kelompok II, III dan IV dilakukan pemberian minuman berenergi.

Minuman berenergi diberikan masing-masing dengan dosis $72 \mathrm{mg} / 200 \mathrm{gr}$ BB tikus/hari untuk kelompok II dan $216 \mathrm{mg} / 200 \mathrm{gr}$ BB tikus/hari untuk kelompok III dan 360 $\mathrm{mg} / 200 \mathrm{gr} \mathrm{BB}$ tikus/hari untuk kelompok IV.

Untuk keseragaman maka pemberian minuman berenergi dilakukan setiap hari selama 30 hari pada jam $12.00-13.00$ WIB siang. Setelah 30 hari sejak tikus mulai diberikan minuman berenergi maka tikus dibunuh dan diambil organ ginjalnya untuk dibuat sediaan. 


\section{Pembuatan sediaan histologis ginjal tikus}

Tikus dibius dengan menggunakan eter, abdomen tikus dibedah untuk mengambil ginjal tikus, dilakukan potongan secara coronal pada ginjal tikus, potongan ginjal tikus tersebut diletakkan dalam tabung organ dan difiksasi dengan formalin 10\% selama 1 hari, dilakukan dehidrasi dengan merendam pada alkohol bertingkat, yaitu pada konsentrasi 30\%, 50\%, 70\%, 85\%, 95\% dan 2 kali alkohol absolute masing-masing selama 30 menit, dilakukan clearing dengan menggunakan alkohol dan xilol dengan perbandingan alkohol : xilol $=3: 1.1: 1,1: 3$ dan 2 kali xilol murni masing-masing selama 60 menit, dilakukan proses infiltrasi dengan xilol dan paraffin dengan perbandingan xilol : paraffin $=3: 1,1: 1,1: 3$ dan 2 kali xilol murni pada suhu 460 - $520 \mathrm{C}$ masing-masing 24 jam, dilakukan blocking dengan paraffin keras pada suhu 460-520 C selama 60 menit, Sliding pada rotasi mikrotom $6 \mu \mathrm{m}$ dengan arah potongan coronal pada ginjal, kemudian direkatkan pada kaca obyek, panaskan pada suhu 460-520 C dalam inkubator selama 24 jam, dilakukan deparafinasi yaitu dengan perendaman xilol dua kali, alkohol absolut, 95\%, $85 \%, 70 \%, 50 \%, 30 \%$, dan $\mathrm{H} 2 \mathrm{O}$ masing-masing selama 3 menit, dan terakhir dilakukan pewarnaan Hematoxilin Eosin.

\section{Pengamatan hasil}

Sediaan diamati dengan mikroskop cahaya dengan pembesaran 400x untuk mengamati perubahan struktur histologis potongan koronal ginjal tikus.

\section{Analisis Data}

Analisis statistik yang digunakan adalah:

1. One way $A N O V A$, yaitu untuk menguji hipotesis kesamaan rata-rata antar kelompok ( $>2$ kelompok), apakah rata-rata antar sampel berbeda secara signifikan atau tidak; dengan tingkat kepercayaan $\mathrm{p}=0,05$, di mana apabila diperoleh $\mathrm{p}>0,05$ artinya tidak ada perbedaan yang bermakna sebaliknya bila $\mathrm{p}<0,05$ menunjukkan adanya perbedaan yang bermakna.

2. Uji Tukey $5 \%$ merupakan uji kelanjutan dari uji ANOVA, digunakan untuk mengetahui perbedaan yang bermakna antar kelompok perlakuan dalam penelitian.

3. Uji korelasi digunakan untuk mengetahui pengaruh yang signifikan antara dosis minuman berenergi dengan jumlah sel nekrosis pada sel epitel tubulus proksimal ginjal.

4. Uji regresi linier untuk mengetahui seberapa kuat pengaruh antara dosis minuman berenergi dengan jumlah sel nekrosis pada sel epitel tubulus proksimal ginjal

\section{HASIL DAN ANALISIS PENELITIAN}

Hasil pengamatan preparat ginjal secara histologis dilakukan menggunakan mikroskop cahaya dengan perbesaran 400x.

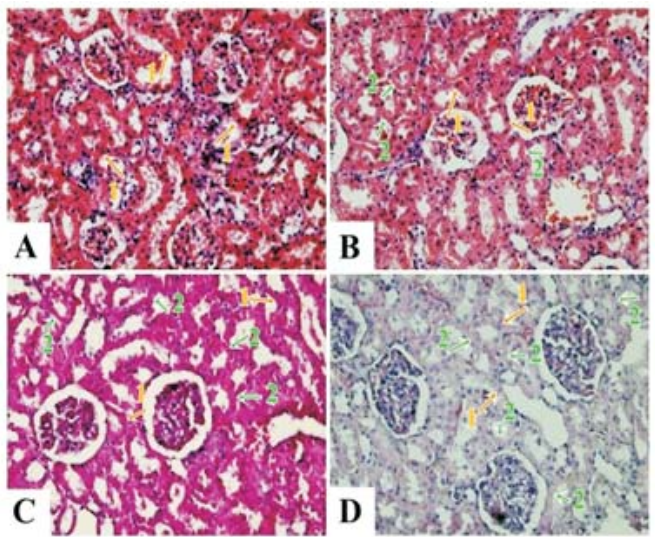

Gambar 1. Gambaran mikroskopis ginjal dengan perbesaran 400x. A=kelompok kontrol (tanpa pemberian minuman berenergi) $\mathrm{B}=$ kelompok perlakuan $\mathrm{I}$ (minuman berenergi $72 \mathrm{mg}$ ) $\mathrm{C}=$ kelompok perlakuan II (minuman berenergi $216 \mathrm{mg}$ ) $\mathrm{D}=$ kelompok perlakuan III

(minuman berenergi $360 \mathrm{mg}$ ). (1) sel epitel tubulus proksimal normal, (2) sel epitel tubulus proksimal yang mengalami nekrosis.

Setiap kelompok perlakuan terdapat 6 preparat sesuai dengan jumlah sampel yang sudah ditentukan kemudian setiap preparat dilakukan penghitungan sel per 10 lapang pandang dengan perbesaran 400x. Pengamatan sel diamati oleh spesialis patologi anatomi FK UMM (dr. Soebarkah Basuki, Sp.PA).

Dalam pengujian efek pemberian minuman berenergi subakut terhadap gambaran histologi ginjal tikus putih strain wistar, digunakan variasi dosis yang berbeda untuk masing-masing perlakuan yaitu dosis $72 \mathrm{mg} / 200 \mathrm{gr} \mathrm{BB} /$ hari, $216 \mathrm{mg} / 200 \mathrm{gr} \mathrm{BB} /$ hari dan dosis $360 \mathrm{mg} / 200 \mathrm{gr}$ BB/hari yang dilakukan selama 30 hari. Digunakan pembanding sebagai kontrol yaitu yang tidak diberi minuman berenergi.

Kemudian tikus dimatikan dan dilakukan proses pembedahan dengan tujuan pengambilan organ ginjalnya untuk mengamati jumlah sel nekrosis pada sel epitel tubulus proksimal ginjal tikus putih strain wistar tersebut. Pengamatan selanjutnya dilakukan dalam 10 lapangan pandang dengan 6 kali pengulangan. Hasil dari penelitian adalah sebagaimana tertera pada Tabel 5.1 sebagai berikut.

Tabel 5.1 Hasil penelitian jumlah sel nekrosis pada sel epitel tubulus proksimal ginjal tikus putih strain wistar

\begin{tabular}{cccccccc}
\hline \multirow{7}{*}{ Perlakuan } & \multicolumn{7}{c}{ Ulangan sampel (\%) } \\
\cline { 2 - 7 } & 1 & 2 & 3 & 4 & 5 & 6 & \\
\hline K & 7.246 & 10.510 & 9.752 & 10.714 & 9.519 & 11.756 & $9.92 \pm 1.53$ \\
P1 & 23.655 & 21.656 & 22.908 & 23.043 & 22.994 & 22.699 & $22.83 \pm 0.66$ \\
P2 & 33.815 & 38.113 & 41.511 & 43.826 & 39.576 & 37.777 & $39.10 \pm 3.44$ \\
P3 & 53.265 & 56.190 & 55.572 & 54.891 & 52.247 & 51.372 & $53.92 \pm 1.93$ \\
\hline
\end{tabular}

Perbedaan dosis minuman berenergi memberikan pengaruh atau efek yang berbeda terhadap jumlah sel nekrosis pada sel epitel tubulus proksimal ginjal tikus putih strain wistar. Adanya pengaruh pemberian minuman berenergi tersebut mulai terlihat, dimana jumlah sel nekrosis pada sel epitel tubulus proksimal ginjal tikus putih strain 
wistar menjadi lebih banyak setelah diberikan perlakuan (P1) berupa minuman berenergi $72 \mathrm{mg} / 200$ gr BB/hari, dibandingkan dengan jumlah sel nekrosis pada kelompok kontrol.

Kemudian jumlah sel nekrosis pada sel epitel tubulus proksimal ginjal tikus putih strain wistar cenderung semakin meningkat ketika diberi minuman berenergi $216 \mathrm{mg} / 200 \mathrm{gr}$ BB/hari dan $360 \mathrm{mg} / 200$ gr BB/hari. Dengan demikian, berdasarkan penilaian secara deskriptif menurut ratarata jumlah sel nekrosis pada sel epitel tubulus proksimal ginjal tikus putih strain wistar tersebut, maka dapat dikatakan bahwa pemberian perlakuan berupa minuman berenergi dengan dosis $72 \mathrm{mg} / 200 \mathrm{gr} \mathrm{BB} / \mathrm{hari}, 216 \mathrm{mg} / 200 \mathrm{gr} \mathrm{BB} /$ hari dan dosis $360 \mathrm{mg} / 200 \mathrm{gr} \mathrm{BB} /$ hari yang dilakukan selama 30 hari tersebut, menunjukkan adanya pengaruh yang berbeda jika dibandingkan dengan kontrol terhadap jumlah sel nekrosis pada sel epitel tubulus proksimal ginjal tikus putih strain wistar.

Adapun adanya perbedaan jumlah sel nekrosis pada sel epitel tubulus proksimal ginjal tikus putih strain wistar secara keseluruhan pada setiap perlakuan di atas juga dapat digambarkan dalam bentuk grafik sebagai berikut.

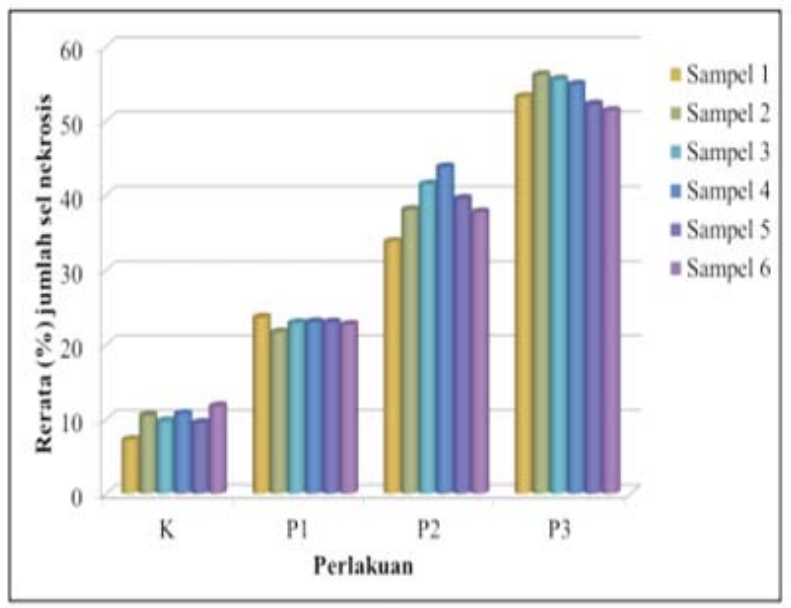

Gambar 2. Grafik jumlah sel nekrosis pada sel epitel tubulus proksimal ginjal tikus putih strain wistar

\section{Analisis Penelitian}

Hasil penelitian dianalisis dengan software SPSS release 15, dan output hasil analisis dapat dilihat pada lembar lampiran (Lampiran 1).

Sebelum melakukan analisis data terhadap efek pemberian minuman berenergi terhadap jumlah sel nekrosis pada sel epitel tubulus proksimal ginjal tikus putih strain wistar dari hasil penelitian (Lampiran 1) dengan menggunakan One way ANOVA, maka diperlukan pemenuhan atas beberapa asumsi data, yaitu data harus mempunyai sebaran normal dan mempunyai ragam yang homogen.

Berdasarkan pengujian normalitas data dengan menggunakan Uji Kolmogorov-Smirnov, terlihat bahwa data variabel yang akan diuji, yaitu data jumlah sel nekrosis pada sel epitel tubulus proksimal ginjal tikus putih strain wistar dari hasil penelitian menunjukkan nilai signifikansi sebesar 0.093 ( $p>0,05)$ sehingga dapat disimpulkan bahwa data variabel tersebut menyebar mengikuti sebaran normal. Dengan demikian dapat dilakukan pengujian dengan
ANOVA, karena asumsi kenormalan distribusi data telah terpenuhi.

Untuk mendeteksi ada atau tidaknya heterogenitas menurut Santoso, S. \& Tjiptono, F (2002) dilakukan dengan menggunakan uji kesamaan ragam yaitu uji Levene (Levene test homogeneity of variances).

Penelitian ini menggunakan variabel numerik dengan satu faktor yang ingin diketahui yaitu perbedaan dari jumlah sel nekrosis pada sel epitel tubulus proksimal ginjal tikus putih strain wistar pada setiap perlakuan terutama yang disebabkan oleh pemberian minuman berenergi dengan 3 variasi dosis minuman berenergi yang diuji coba di laboratorium (72 mg/200gr BB/hari, $216 \mathrm{mg} / 200 \mathrm{gr} \mathrm{BB} /$ hari, dan dosis $360 \mathrm{mg} / 200 \mathrm{gr} \mathrm{BB} /$ hari), ditambah dengan kontrol (tanpa diberi minuman berenergi).

Selanjutnya berdasarkan hasil penelitian berupa jumlah sel nekrosis pada sel epitel tubulus proksimal ginjal tikus putih strain wistar pada lampiran, kemudian diolah dan dianalisis, untuk mengetahui adanya perbedaan pengaruh dari variasi dosis pemberian minuman berenergi terhadap jumlah sel nekrosis pada ginjal tikus putih strain wistar, dengan menggunakan analisis oneway ANOVA (Analysis of Variance).

Langkah selanjutnya adalah mengolah data yang ada dengan menggunakan metode post hoc test sebagai uji pembandingan berganda (multiple comparisons) dengan uji Tukey (Tukey's Test) sebagai salah satu uji pembandingan berganda yang mempunyai sensitivitas cukup tinggi dalam menguji adanya perbedaan antar perlakuan dalam multiple comparisons. Dengan metode ini akan dilakukan pembandingan yang berganda terhadap jumlah sel nekrosis pada sel epitel tubulus proksimal ginjal tikus putih strain wistar antara setiap perlakuan. Sehingga untuk mengetahui adanya perbedaan pengaruh pemberian minuman berenergi terhadap jumlah sel nekrosis pada sel epitel tubulus proksimal ginjal tikus putih strain wistar pada setiap dosis yang diberikan tersebut.

Untuk mengetahui besarnya hubungan dan pengaruh dari pemberian minuman berenergi dengan jumlah sel nekrosis pada sel epitel tubulus proksimal ginjal tikus putih strain wistar, maka digunakan uji korelasi dan regresi linier, dengan hasil pengujian pada lampiran.

Berdasarkan hasil analisis pada Tabel 5.5 di atas dapat diketahui bahwa pemberian minuman berenergi dengan jumlah sel nekrosis pada sel epitel tubulus proksimal ginjal tikus putih strain wistar mempunyai hubungan (korelasi) $(\mathrm{r}=0.988, \mathrm{p}=0.000)$ yang signifikan $(\mathrm{p}<0.05)$ dengan arah korelasi yang positif (karena koefisien korelasi bernilai positif). Artinya semakin tinggi dosis pemberian minuman berenergi cenderung akan diikuti oleh peningkatan jumlah sel nekrosis pada sel epitel tubulus proksimal ginjal tikus putih strain wistar. Demikian sebaliknya, semakin rendah dosis pemberian minuman berenergi cenderung akan diikuti oleh penurunan jumlah sel nekrosis pada sel epitel tubulus proksimal ginjal tikus putih strain wistar. Seberapa besar pengaruh pemberian minuman berenergi dengan jumlah sel nekrosis pada sel epitel tubulus proksimal ginjal tikus putih strain wistar, dapat diketahui dengan menggunakan analisis bentuk hubungan (regresi), karena dari uji korelasi belum bisa menjelaskan hal tersebut. 
Adapun model regresi dari pengaruh pemberian minuman berenergi dengan jumlah sel nekrosis pada sel epitel tubulus proksimal ginjal tikus putih strain wistar yaitu $\mathrm{Y}=12.104+0.040 \mathrm{X}$, dimana $\mathrm{Y}$ adalah jumlah sel nekrosis pada sel epitel tubulus proksimal ginjal tikus putih strain wistar, sedangkan $\mathrm{X}$ adalah dosis pemberian minuman berenergi.

Hal ini dapat diartikan bahwa tanpa dipengaruhi oleh pengaruh pemberian minuman berenergi, maka jumlah sel nekrosis pada sel epitel tubulus proksimal ginjal tikus putih strain wistar akan cenderung meningkat secara konstan $12.104 \%$ (karena koefisien konstanta bernilai positif). Namun apabila dipengaruhi oleh perlakuan pemberian minuman berenergi, hal ini justru akan semakin meningkatkan jumlah sel nekrosis pada sel epitel tubulus proksimal ginjal tikus putih strain wistar hingga $0,040 \%$ untuk setiap peningkatan dosis $1 \mathrm{mg} / 200 \mathrm{gr} \mathrm{BB} /$ hari.

Berdasarkan hasil uji regresi juga menunjukkan nilai koefisien determinasi ( $\mathrm{R}$ Square $=\mathrm{r} 2$ ) yang menyatakan besarnya pengaruh dari pemberian minuman berenergi terhadap jumlah sel nekrosis pada sel epitel tubulus proksimal ginjal tikus putih strain wistar, dalam bentuk persentase, dan persentase sisanya (1 - R Square) ditentukan oleh faktor lain. Jadi dapat dikatakan bahwa pemberian minuman berenergi sangat berpengaruh terhadap jumlah sel nekrosis pada sel epitel tubulus proksimal ginjal tikus putih strain wistar hingga $97.6 \%$. Sedangkan $2.4 \%$ keragaman jumlah sel nekrosis pada sel epitel tubulus proksimal ginjal tikus putih strain wistar tersebut dipengaruhi oleh faktor lain selain dari pemberian minuman berenergi seperti pengaruh variabel luar yang tidak dapat dikendalikan misalnya kondisi psikologis tikus yang dipengaruhi lingkungan sekitar, reaksi hipersensitivitas yang berbeda pada tiap tikus terhadap zat yang digunakan, atau kondisi awal ginjal yang tidak diteliti pada penelitian ini sehingga mungkin saja ada tikus yang sebelum perlakuan ginjalnya sudah mengalami kelainan (Maulana, 2010).

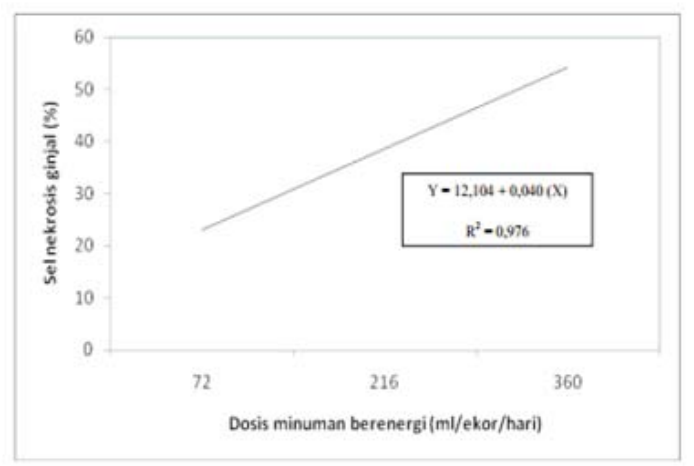

Gambar 3. Grafik Linieritas

Berdasarkan grafik linieritas di atas terlihat bahwa garis regresi antara pemberian minuman berenergi dengan jumlah sel nekrosis pada sel epitel tubulus proksimal ginjal tikus putih strain wistar mengarah ke kanan atas. Hal ini membuktikan adanya linieritas dari pemberian minuman berenergi dengan jumlah sel nekrosis pada sel epitel tubulus proksimal ginjal tikus putih strain wistar. Artinya peningkatan perlakuan berupa pemberian dosis minuman berenergi cenderung akan meningkatkan jumlah sel nekrosis pada sel epitel tubulus proksimal ginjal tikus putih strain wistar, dibandingkan dengan jumlah sel nekrosis pada sel epitel tubulus proksimal ginjal tikus putih strain wistar pada kelompok yang diberi minuman berenergi dengan dosis yang lebih rendah.

\section{PEMBAHASAN}

Penelitian ini merupakan penelitian eksperimental dengan metode the posttest only group design yang membuktikan pengaruh pemberian minuman berenergi terhadap gambaran histologi ginjal tikus putih strain wistar yang dilakukan selama 30 hari dengan dosis yang telah ditentukan.

Pada penelitian ini dilakukan uji kuantitatif dengan mengamati tubulus proksimal ginjal tikus secara mikroskopik. Setelah pemberian minuman berenergi dengan berbagai dosis didapatkan peningkatan jumlah sel nekrosis pada sel epitel tubulus proksimal ginjal tikus putih strain wistar. Pada kelompok kontrol jumlah sel nekrosis pada sel epitel tubulus proksimal hanya 9,92\%. Namun setelah pemberian minuman berenergi dengan dosis $72 \mathrm{mg} / 200 \mathrm{gr}$ $\mathrm{BB} /$ hari (P1), $216 \mathrm{mg} / 200 \mathrm{gr} \mathrm{BB} /$ hari (P2) dan $360 \mathrm{mg} /$ 200 gr BB/hari (P3) didapatkan peningkatan jumlah sel nekrosis pada sel epitel tubulus proksimal pada masingmasing kelompok mencapai 22,83\%, 39,10\% dan 53,92\%.

Dengan demikian, berdasarkan penilaian secara deskriptif menurut ratarata jumlah sel nekrosis pada sel epitel tubulus proksimal ginjal tikus putih strain wistar tersebut, maka dapat dikatakan bahwa pemberian perlakuan berupa minuman berenergi dengan dosis yang bervariasi selama 30 hari tersebut, menunjukkan adanya peningkatan jumlah sel nekrosis pada sel epitel tubulus proksimal ginjal tikus putih strain wistar yang signifikan.

Hal ini didukung dengan penelitian terdahulu yang membuktikan bahwa setelah pemberian minuman berenergi merek X selama 30 hari dengan dosis bervariasi terjadi penurunan fungsi ginjal yang cukup tajam (Nova, 2009). Pada kelompok II dengan dosis $5 \mathrm{ml} / 200$ gr BB/hari memperlihatkan penurunan fungsi ginjal sebesar $60 \%$, kelompok III dengan dosis $10 \mathrm{ml} / 200 \mathrm{gr} \mathrm{BB} /$ hari sebesar $34 \%$ dan kelompok IV dengan dosis $15 \mathrm{ml} / 200 \mathrm{gr} \mathrm{BB} /$ hari sebesar 15\%. Hal ini menunjukkan bahwa 75\% massa nefron ginjal telah hancur sehingga fungsi ginjal menurun.

Fungsi ginjal yang menurun ditunjukkan dengan menurunya volume urine, kadar kreatinin urine dan klirens kreatinin (Price, 2005). Efek pemberian minuman berenergi selama 1 bulan pada tikus bila dikonversikan pada manusia adalah 20 bulan. Konversi ini sesuai dengan perhitungan konversi umur manusia 60 tahun, sedangkan tikus 3 tahun (Malole, 1989).

Pada pengujian hipotesis dengan menggunakan uji oneway ANOVA didapatkan nilai signifikansi sebesar 0.000 $(\mathrm{p}<0,05)$, sehingga dapat disimpulkan bahwa terdapat perbedaan jumlah sel nekrosis pada sel epitel tubulus proksimal ginjal tikus putih strain wistar yang signifikan sebagai efek dari pemberian minuman berenergi. 
Selanjutnya dilakukan uji tukey untuk mengetahui adanya perbedaan pengaruh pemberian minuman berenergi terhadap jumlah sel nekrosis pada sel epitel tubulus proksimal ginjal tikus putih strain wistar pada setiap dosis yang diberikan. Dengan menggunakan uji tukey didapatkan nilai signifikansi sebesar $0.000(p<0,05)$ antara kelompok, sehingga dapat disimpulkan bahwa terdapat perbedaan yang bermakna antara kelompok kontrol dengan kelompok perlakuan dan antara kelompok antara kelompok perlakuan yang diberikan minuman berenergi dengan dosis yang bervariasi.

Pada uji korelasi didapatkan $r=0.988$ dan $\mathrm{p}=0.000$, sehingga dapat disimpulkan bahwa pemberian minuman berenergi dengan jumlah sel nekrosis pada sel epitel tubulus proksimal ginjal tikus putih strain wistar mempunyai hubungan yang signifikan $(\mathrm{p}<0.05)$ dengan arah korelasi yang positif, artinya semakin tinggi dosis pemberian minuman berenergi cenderung akan diikuti oleh peningkatan jumlah sel nekrosis pada sel epitel tubulus proksimal ginjal tikus putih strain wistar.

Pada uji regresi didapatkan $\mathrm{R} 2=0,976$ yang artinya bahwa pemberian minuman berenergi sangat berpengaruh terhadap jumlah sel nekrosis pada sel epitel tubulus proksimal ginjal tikus putih strain wistar hingga 97,6\%, sedangkan 2,4\% keragaman jumlah sel nekrosis pada sel epitel tubulus proksimal ginjal tikus putih strain wistar tersebut dipengaruhi oleh faktor lain selain dari pemberian minuman berenergi seperti pengaruh variabel luar yang tidak dapat dikendalikan.

Terjadinya kerusakan pada sel tubulus proksimal ginjal tikus setelah pemberian minuman berenergi tersebut sesuai dengan teori bahwa ekskresi obat yang berlangsung di ginjal dapat menimbulkan dampak buruk bagi ginjal itu sendiri (Robbins, 2005). Hal tersebut berkaitan dengan fungsi utama dari ginjal yaitu sebagai organ eliminasi penting bagi tubuh. Beberapa macam faktor yang mempengaruhi kerentanan ginjal terhadap efek toksik salah satunya adalah walaupun berat ginjal hanya sekitar $0,5 \%$ dari total berat badan, tetapi ginjal menerima aliran darah sebesar $20-25 \%$ dari curah jantung melalui arteri renalis. Tingginya aliran darah yang menuju ginjal inilah yang menyebabkan berbagai macam obat dan bahan-bahan kimia dalam sirkulasi sistemik dikirim ke ginjal dalam jumlah yang besar (Schnellmann, 2001).

Zat-zat toksik ini akan terakumulasi di ginjal dan sebagai akibatnya akan terjadi proses perubahan struktur dari ginjal itu sendiri, terutama di tubulus ginjal karena disinilah terjadi proses reabsorpsi dan eksresi dari zat- zat toksik tersebut (Hodgson, 2005). Salah satu manifestasi yang sering ditemukan akibat zat nefrotoksik dalam ginjal adalah gagal ginjal akut terutama dalam bentuk nekrosis tubular akut (NTA). Adanya kerusakan dalam tubulus ginjal akibat zat nefrotoksik ini dilihat dengan adanya: penyempitan tubulus kontortus proksimal, nekrosis sel epitel tubulus kontortus proksimal dan adanya hialin cast di tubulus distal (Alpers, 2007; Underwood, 2000).

Di samping itu, kafein merupakan antagonis reseptor adenosin A1 yang menyebabkan penghambatan efek renovaskular dan menyebabkan sekresi angiotensin meningkat (Tofovic, 2002). Angiotensin akan memicu vasokontriksi arteriol, hipoperfusi kapiler peritubuler postglomerulus dan hipoksia tubulointerstisial yang akan mengurangi pengiriman oksigen dan nutrisi ke tubulus sehingga dapat menyebabkan kerusakan tubulus (Nangaku, 2006).

Kafein juga merupakan antagonis reseptor adenosin A2a yang menyebabkan aktivasi polymorphonuclear cell (PMN) meningkat sehingga dapat meningkatkan resiko inflamasi yang selanjutnya akan menurunkan fungsi ginjal, menyebabkan proteinuria dan perubahan progresif yang lambat terhadap gambaran histologi ginjal (Moneim, 2009; Geoffrey, 2006). Hal ini juga didukung dengan penelitian terdahulu yang membuktikan bahwa konsumsi kopi yang mengandung kafein akan menyebabkan kerusakan pada sel tubulointersitial dan glomerulus ginjal (Gerhastuti, 2009).

Zat-zat toksik ini akan terakumulasi di ginjal dan sebagai akibatnya akan terjadi proses perubahan struktur dari ginjal itu sendiri, terutama di tubulus ginjal karena disinilah terjadi proses reabsorpsi dan eksresi dari zat- zat toksik tersebut (Hodgson, 2005). Salah satu manifestasi yang sering ditemukan akibat zat nefrotoksik dalam ginjal adalah gagal ginjal akut terutama dalam bentuk nekrosis tubular akut (NTA). Adanya kerusakan dalam tubulus ginjal akibat zat nefrotoksik ini dilihat dengan adanya: penyempitan tubulus kontortus proksimal, nekrosis sel epitel tubulus kontortus proksimal dan adanya hialin cast di tubulus distal (Alpers, 2007; Underwood, 2000).

Dari berbagai fakta yang ditemukan pada penelitian ini dan melalui kajian statistika, maka hipotesis tentang pengaruh pemberian minuman berenergi terhadap peningkatan kerusakan sel ginjal pada tikus putih strain wistar terbukti, namun masih memerlukan penelitian lebih lanjut untuk mengetahui mekanisme pasti minuman berenergi dalam menyebabkan kerusakan sel ginjal.

\section{Kesimpulan}

Kesimpulan penelitian ini adalah sebagai berikut :

1. Ekstrak buah nanas dapat menurunkan kadar LDL, Trigliserida, dan Kolesterol Total tikus putih jantan dislipidemia.

2. Ekstrak buah nanas dapat meningkatkan kadar HDL tikus putih jantan dislipidemia.

3. Pada penelitian ini, penggunaan dosis ekstrak nanas efektif yang dalam memperbaiki profil lipid hingga mendekati normal adalah dosis 4 gr/ekor/hari.

\section{DAFTAR PUSTAKA}

Katzung BG, 1998, Farmakologi Dasar dan Klinik, alih bahasa : Staf Dosen Farmakologi Fakultas Kedokteran UNSRI, EGC, Jakarta.

Kwiterovich PO, Jr., 2000, The Metabolic Pathways of High Density Lipoprotein, Low Density Lipoprotein, and Triglicerides, A Current Review, Am J Cardiol, 86, pp. 510.

Babu KM, Church RJ, Lewander W, 2008, Energy Drinks: The New Eye-Opener For Adolescents, Clin Pediatr Emerg Med, 9(1): 35- 42.

Malinauskas BM, Aeby VG, Overton RF, et al., 2007, A Survey of Energy Drink Consumption Patterns Among College Students, Nutr J, 6:35. 
Malole M, Pramono S, 1989, Penggunaan Hewan-hewan Percobaan Laboratorium. Departemen Pendidikan dan Kebudayaan, Direktorat Jendral Pendidikan Tinggi Pusat Antar Universitas Bioteknologi, Institut Pertanian Bogor.

Nova R. Mandasari, 2011, Efek Pemberian Subakut Minuman Energi Merek X Terhadap Fungsi Ginjal Pada Tikus Putih Jantan (Rattus norvegicus) Strain Wistar, Tugas Akhir, Fakultas Kedokteran Universitas Muhammadiyah Malang.

Stevan P. Tofovic, Curtis K. Kost, Edwin K. Jackson, et al., 2002, Long Term Caffeine Consumption Exacerbates Renal Failure in Obese, Diabetic, ZSF1 (Fa-Facp) Rats, Kidney Int, 61: 1433-1444.

Stewart J, 2002, Clinical Anatomy and Patophysiology, Mc Graw-Hill, Singapore.

Nangaku M, 2006, Chronic Hypoxia and Tubulointerstitial Injury: A Final Common Pathway to End-Stage Renal Failure, I Am Soc Nephrol, 17: 17-25. 